\title{
Online Management System Berbasis Web Pada SMK Multistudi High School Batam
}

\author{
Algifanri Maulana ${ }^{1}$, Yvonne Wangdra ${ }^{2}$ \\ ${ }^{1}$ Program Studi Teknik Informatika Fakultas Teknik \& Ilmu Komputer \\ ${ }^{2}$ Program Studi Manajemen Fakultas Ilmu Sosisal \& Humaniora \\ Universitas Putera Batam \\ Jalan R. Soeprapto, Muka Kuning, Batam, telp. 082391287111 \\ e-mail: ${ }^{1}$ algifanri@puterabatam.ac.id, ${ }^{2}$ yvonne@puterabatam.ac.id
}

\begin{abstract}
Abstrak
Merancang sebuah aplikasi dalam pelayanan menejemen sistem Informasi secara online yang berbasis web merupakan tujuan dasar dari penelitian ini. Didalam aplikasi ini di rancang khusus informasi tentang profil sekolah, fasilitas yang ada, prestasi yang pernah di raih, memberi kemudahan dalam registrasi siswa baru, pemberitahuan pembayaran SPP, dan kondisi keuangan sekolah sehingga menjadi profile lengkap dari sebuah sekolah. Dengan demikian dapat menjadi transparansi bagi siswa dalam mengikuti setiap kegiatan. Aplikasi ini menggunakan sistem pelayanan dalam bentuk digital dirancang dengan menggunakan Bahasa ASP menggunakan Visual Studio dan database SQL Server. Sistem pelayanan dan transaksi digital akan membantu seluruh orang tua dalam menentukan pilihan bagi putra putrinya. Metode penelitian ini menggunakan metode analisa deskriptif kualitatif oleh karena itu pengumpulan data dilakukan dengan cara observasi dan teknik wawancara.
\end{abstract}

Kata kunci: online management, system informasi, manajemen pelayanan

\begin{abstract}
Designing an application in web-based online information system management services is the basic objective of this research. In this application specially designed information about school profiles, existing facilities, achievements that have been achieved making it easy to register new students, notification of tuition payments, and the financial condition of the school so that it becomes a complete profile of a school. Thus it can become transparency for students in participating in each activity. This application uses a service system in digital form designed using the ASP Language using Visual Studio and SQL Server databases. The digital service and transaction system will help all parents in making choices for their children. This research method uses descriptive qualitative analysis method therefore data collection is done by observation and interview techniques.
\end{abstract}

Keywords: online management, information systems, service management

\section{Pendahuluan}

Industry 4.0 merupakan tekhnologi termutakhir yang sedang populer dalam dunia tekhnologi saat ini. Tekhnologi yang dimaksud khususnya dalam pelayanan transaksi realtime yang cepat sehingga komunikasi dan transaksi dapat terjadi secara otomatis tanpa mengenal ruang dan waktu. Komputerisasi telah terintegrasi disetiap bidang pekerjaan manusia sehigga tidak dapat di pungkiri kecanggiha tekhnologi merupakan suatu kebutuhan dalam memudahkan pekerjaan manusia [1].

Salah satu bidang yang tidak lepas dari kebutuhan akan tekhnologi adalah bidang pendidikan. Kualitas suatu negara sangat bergantung pada sumber daya manusianya. Oleh 
karena itu, pendidikan merupakan unsur penting dalam mempengaruhi kemajuan sebuah negara. Tidak dapat dipungkiri, dalam bidang pendidikan negara Indoesia masih jauh tertinggal dari negara - negara berkembang lainnya.

Batam merupakan salah satu kota industry yang cukup pesat di Indonesia. Uniknya kota ini berbatasan langsung dengan negara berkembang seperti Singapur dan Malaysia yang mana sistem pendidikan mereka sudah menerapkan sistem pelayanan pendidikan yang dapat di akses melalui tekhnologi termutakhir saat ini. Hal ini berbanding terbalik dengan dunia pendidikan di Indonesia khususnya kota Batam. Hal ini dapat di lihat dari sistem pendidikan yang terdapat di sekolah -sekolah di kota Batam masih menggunakan sistem konvensional. Artinya, kemutakhiran tekhnologi revolusi 4.0 yang sedang populer masih menjadi wacana khususnya di bidang pendidikan sekolah - sekolah yang ada di kota Batam. Sistem pendidikan yang memberikan pelayanan yang mudah dan efektif sesuai dengan arahan pemerintah dengan tujuan peningkatan kualitas pendidikan masih menjadi tugas rumah yang perlu mendapatkan perhatian khusus [2]. Tuntutan peningkatan kualitas pendidikan dari pemerintah ini belum berbanding lurus dengan kenyataan yang terjadi di lapangan karena masih banyaknya hal yang harus dibenahi khususnya dalam bidang pendidikan. Sehingga tujuan dalam memperbaiki kualitas pelayan terhadap masyarakat dapat terwujud. Ada empat unsur penting dalam mewujudkan kualitas peningkatan pelayanan masyarakat yang baik. Yaitu harus adanya pelaayanan yang cepat, pelayanan yang baik, pelayanan yang adil dan pelayanan yang murah. Seperti yang diketahui bahwa terjadi beberapa sistem kurikulum yang berubah - ubah dalam beberapa tahun terakhir. Terlebih lagi perubahan kurikulum ini berpengaruh pada mata pelajaran yang di ikutkan dalam Ujian Nasional.

Perubahan - perubahan aturan kurikulum, sistem pendaftaran siswa baru, dan masih banyak lagi permasalahan - permasalahan yang ditemukan dalam bidang pendidikan ini menjadi permasalahan yang serius. Oleh karena itu, perlu adanya sebuah sistem yang dapat memberikan informasi yang cepat baik bagi admin yang bertugas di sebuah sekolah dalam menyediakan informasi yang dibutuhkan oleh masyarakat misalnya dalam mensosialisasikan sebuah perubahan atau aturan dalam sistem pendidikan. Selain bagi pihak sekolah, masyarakat yang sedang mencari informasi tentang profil sekolah juga dapat dengan cepat mendapatkan berita dan informasi sehingga dapat memudahkan dalam pemenuhan kebutuhan informasi khususnya dalam bidang pendidikan ini [3].

Salah satu pelayanan masyarakat dalam bidang pendidikan di sekolah ini adalah pelaksanaa kegiatan yang sudah tercover dalam biaya pendidikan Bantuan Operasional Sekolah atau dana BOS. Artinya, setiap kegiatan yang diadakan pihak sekolah dapat di ikuti setiap siswa tanpa membayar atau tanpa pungutan biaya. Namun dapat pula dipahami, bila ada pungutuan biaya untuk item tertentu merupakan kesepakatan antara pihak sekolah, pihak komite sekolah, wali murid, serta stakeholder yang terlibat. Mengingat dana yang di berikan oleh pemerintah untuk setiap sekolah sudah dapat dikatakan sangat besar sehingga kegiatan - kegiatan yang telah dijelaskan sebelumnya dapat di cover dari dana BOS. Dengan demikian, seharusnya setiap sekolah dapat mempertanggung jawabkan anggaran pembelanjaan kebutuhan sekolah. Sangat aneh apabila sebuah sekolah mendapatkan bantuan dana yang cukup besar dari pemerintah guna membiayai seluruh kegiatan yang berkaitan dengan sekolah namun masih memberlakukan kewajiban pemungutan biaya pada setiap siswa. Selain itu, pendanaan BOS ini juga di tujukan untuk pemeliharaan fasilitas sekolah seperti perpustakaan, pemenuhan kebutuhan buku, laboraturium dan fasilitas lainnya [4].

Dari uraian diatas, penelitian ini fokus pada tiga hal penting. Yang pertama bahwa penelitian ini dilaksanakan di sekolah kejuruan SMK Multistudi High School. Yang kedua penelitian ini fokus pada Teknologi yang digunakan menggunakan Bahasa pemrograman ASP 
dan juga menggunakan SQL Server sebagai database. Yang terakhir, data yang diambil berdasarkan transaksi yang sudah dilakukan sebelumnya. Juga penelitian ini akan menghasilkan sebuah sistem informasi yang terintegrasi mulai dari registrasi, kehadiran siswa juga keuangan siswa dalam menjalankan segala aktifitas di sekolah MHS.

\section{Metode Penelitian}

\subsection{Lokasi Penelitian}

SMK Multistudi Highschool merupakan lokasi dari penelitian ini. SMK Multistudi Highschool adalah salah satu sekolah menengah kejuruan yang ada di Kota Batam. Penerapan layanan di sekolah ini masih dalam bentuk manual dan konvensional dalam mengelola data transaksi siswa. Oleh karena itu penelitian ini dapat membantu pihak sekolahan untuk memiliki online management system berbasis web. Metode kualitatif adalah metode yang dianggap tepat dalam menguraikan data penelitian yag didapat. Selain itu, observasi langsung juga dilakuka pada sistem layanan transaksi yang ada di SMK Multistudi High School Kota Batam.

\subsection{Metode Perancangan}

Aplikasi Visual studio berbasis web merupakan langkah - langkah penting dalam perancangan sistem ini yaitu penggunaan teknologi ASP yang mana akan di control melalui server windows dengan database SQL Server yang berfungsi dalam mengontrol pengolahan dalam memproses data yang masuk. Dimana nantinya akan memiliki akses.

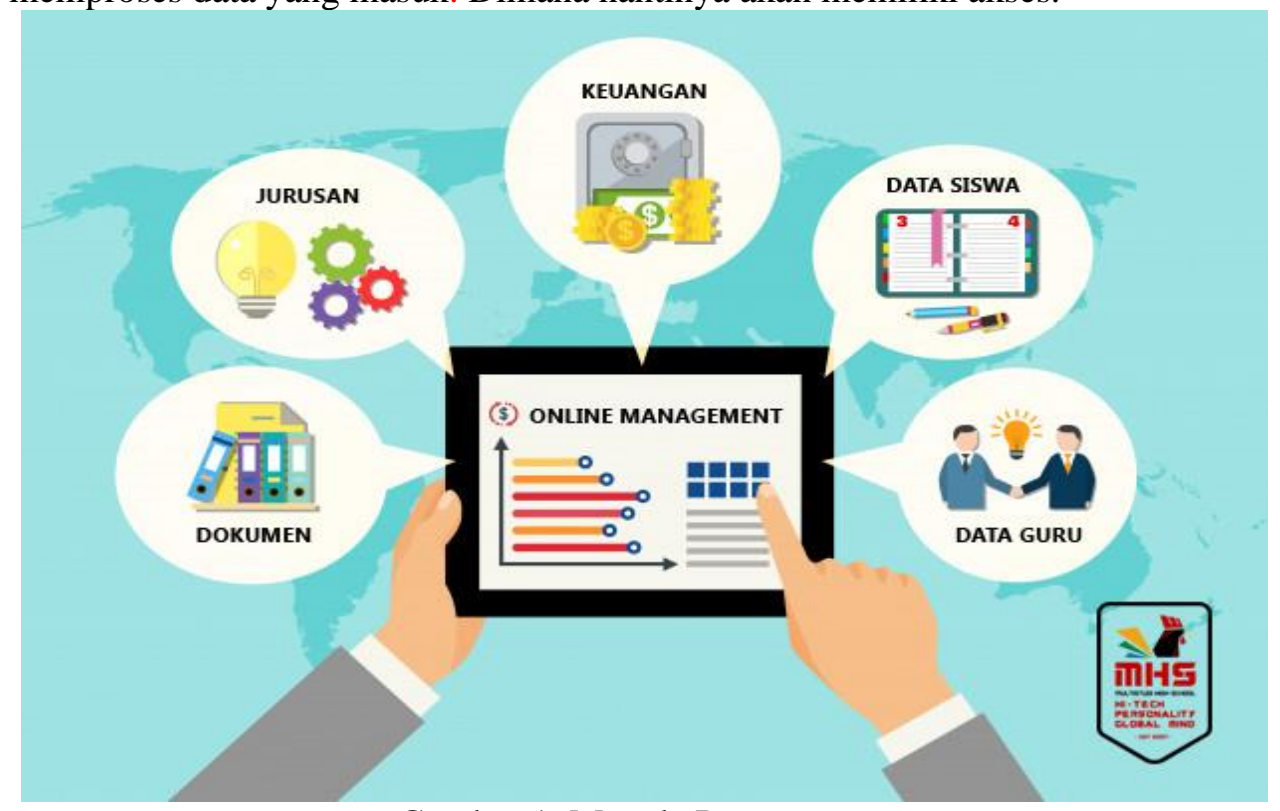

Gambar 1. Metode Perancangan

Ada 5 tahapan unsur dalam perancangan yang akan dibuat berbasis web, yaitu :

1. Dokumen

Pada modul ini berisi semua dokumen yang terkait dengan data - data sekolah, mulai dari dokumen biaya Pendidikan, dokumen profil sekolah hingga ke dokumen bagi siswa yang sudah lulus pada SMK Multistudi.

2. Jurusan

SMK MHS terdapat 3 jurusan yang berbeda, yakni RPL, TKJ dan Akuntansi. Untuk modul jurusan ini digunakan dalam menentukan jurusan calon siswa yang akan sekolah di MHS sehingga dalam manajemennya bias dikelola mulai dari siswa tersebut melakukan pendaftaran hingga lulus nantinya. 


\section{Keuangan}

Menu dalam modul ini nantinya akan meliputi kegiatan manajemen sekolah secara keseluruhan, mulai dari uang pendaftaran siswa baru, spp, uang pembangunan, komite, uang osis siswa serta gaji untuk para guru yang mengajar di sekolah MHS.

4. Data Siswa

Modul ini akan dipakai untuk biodata siswa secara keseluruhan beserta formulir pendaftaran, data ukuran baju dan juga data sekolah SMP asal dari calon siswa yang nantinya akan melanjutkan di SMK MHS. Juga terdapat menu upload dokumen pendaftaran bagi calon siswa.

5. Data Guru

Modul ini berisi tentang wali kelas pada masing - masing jurusan, biodata guru, riwayat pengajaran guru beserta sertifikat keahlian yang dimiliki

\subsection{Metode Pengumpulan Data}

Sebuah penelitian dikatakan valid dan berkualitas apabila data yang dikumpulkan menggunakan metode yang tepat. Data yang masuk dan dikumpulkan melalui serangkaian proses. Adapun proses yang dilalui adalah dengan cara mewawancari objek penelitian yang terlibat agar memenuhi pengumpulan informasi - informasi yang diperlukan. Selain wawancara, metode yang tidak kalah penting adalah observasi. Observasi perlu di lakukan pada awal pengambilan data, saat proses pengumpulan data penelitian maupun setelah pengumpulan data.

\section{Hasil dan Pembahasan}

Tahapan dokumen yang dilakukan untuk pertama kalinya yaitu dengan membuat manajemen online data dalam sebuah website profile sekolah yang berisi tentang dokumen sekolah, jurusan profile guru pada sekolah MHS. Sehingga dokumen yang sudah di tempatkan di online tersebut dapat diakses oleh siapapun yang ingin mengetahui lokasi dan informasi dari sekolah SMK MHS Batam melalui link http://multistudi.sch.id/. Ditampilkan juga pada menu awal calon siswa bisa langsung melakukan registrasi. Apabila melakukan pendaftaran melalui online maka akan mendapatkan potongan harga uang pendaftaran $10 \%$ dan apabila mendaftar langsung ke sekolah tidak menggunakan sistem maka tidak akan mendapatkan potongan harga.

Adapun aturan yang berlaku dalam online registrasi yang sudah dirancang hanya dibatasi setiap gelombangnya dengan kuota maksimal 50 pendaftar pertama. Begitu sudah tercapai maka akan dilanjutkan dengan gelombang pendaftaran berikutnya sampai memenuhi target pendaftaran siswa baru. Dalam perancangannya sistem dibuat berbasi online menggunakan web base dimana ketika akan menggunakan sistem layanan registrasi ini langsung menggunakan browser dengan mengetikkan alamat registrasi.multistudi.sch.id maka akan langsung menampilakan halaman home untuk login ataupun daftar secara online. Ketika calon siswa sudah mendaftar maka sudah bisa langsung menggunakan akun yang telah secara otomatis dikirimkan ke email yang telah didaftarkan. Untuk mendukung desaian sistem layanan transaksi digital berikut adalah ERD pada sistem pelayanan transaksi digital yang telah dirancang untuk mempresentasikan model data yang ada pada sistem. Beberapa unsur penting dalam merancang sebuh sistem yaitu modul siswa, modul gelombang, modul registrasi, dan modul biaya. Sistem yang focus bertugas menyediakan data tentang persediaan dan control stock kuota siswa baru yang sudah terdaftar dalam menggunakan sistem layana digital 


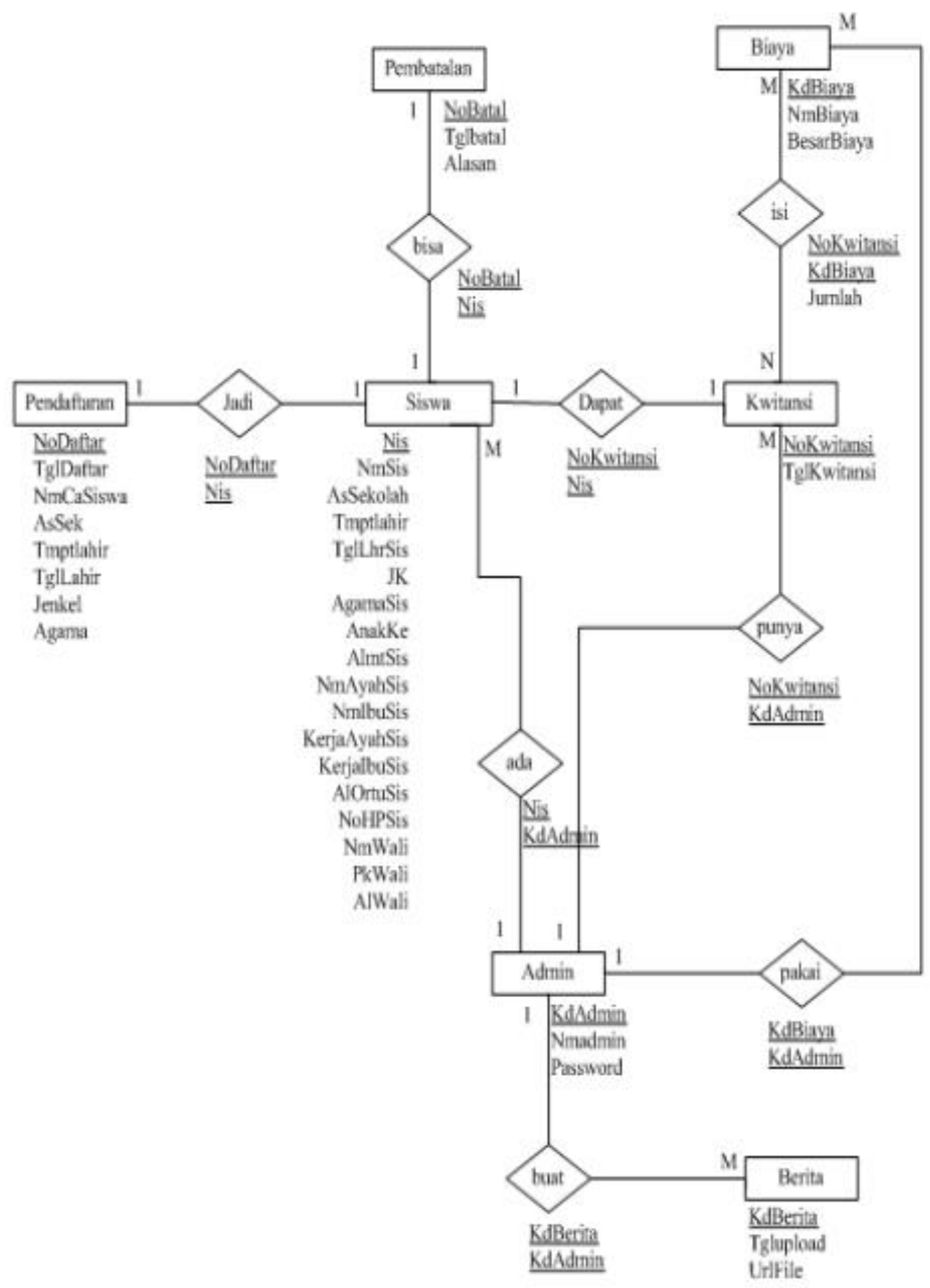

Gambar 1. ERD Online Managemen System 


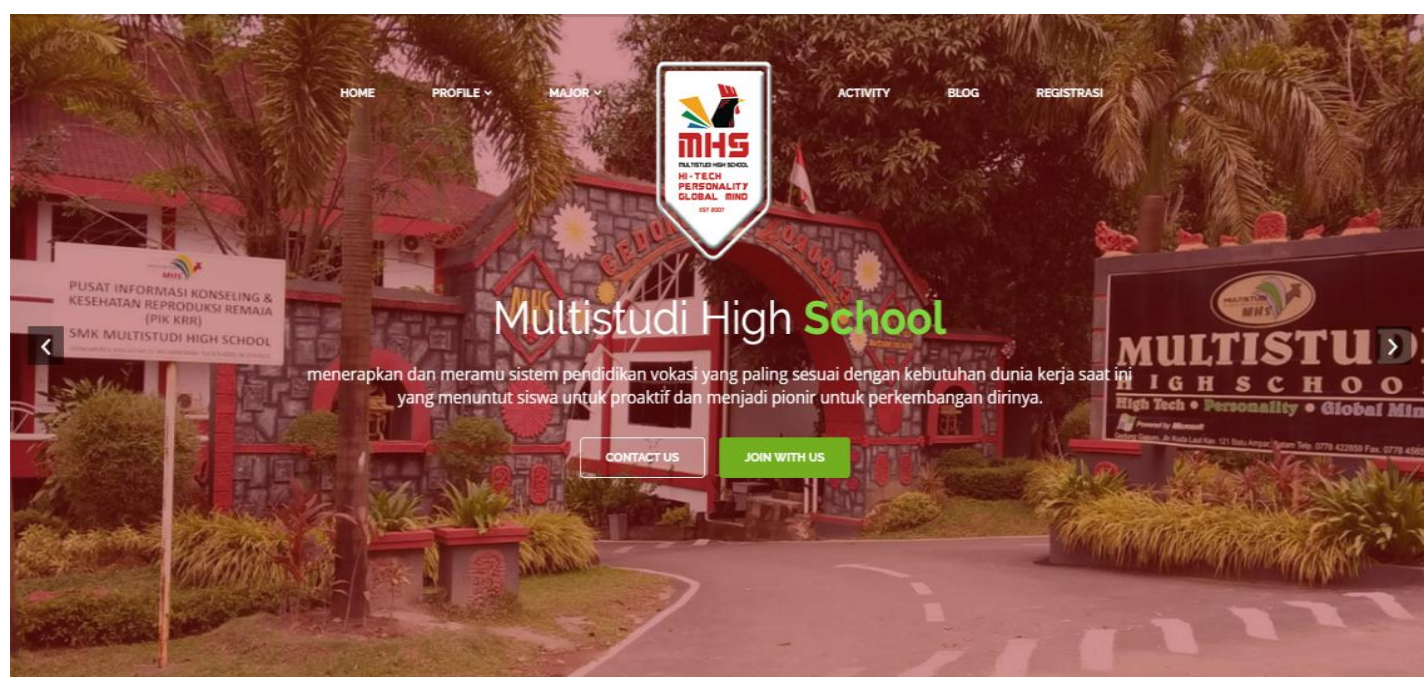

Gambar 2. Website profile MHS

Ketika calon siswa akan mendaftarkan diri maka akan muncul menu registrasi form atau dapat melalui link http://registrasi.multistudi.sch.id/

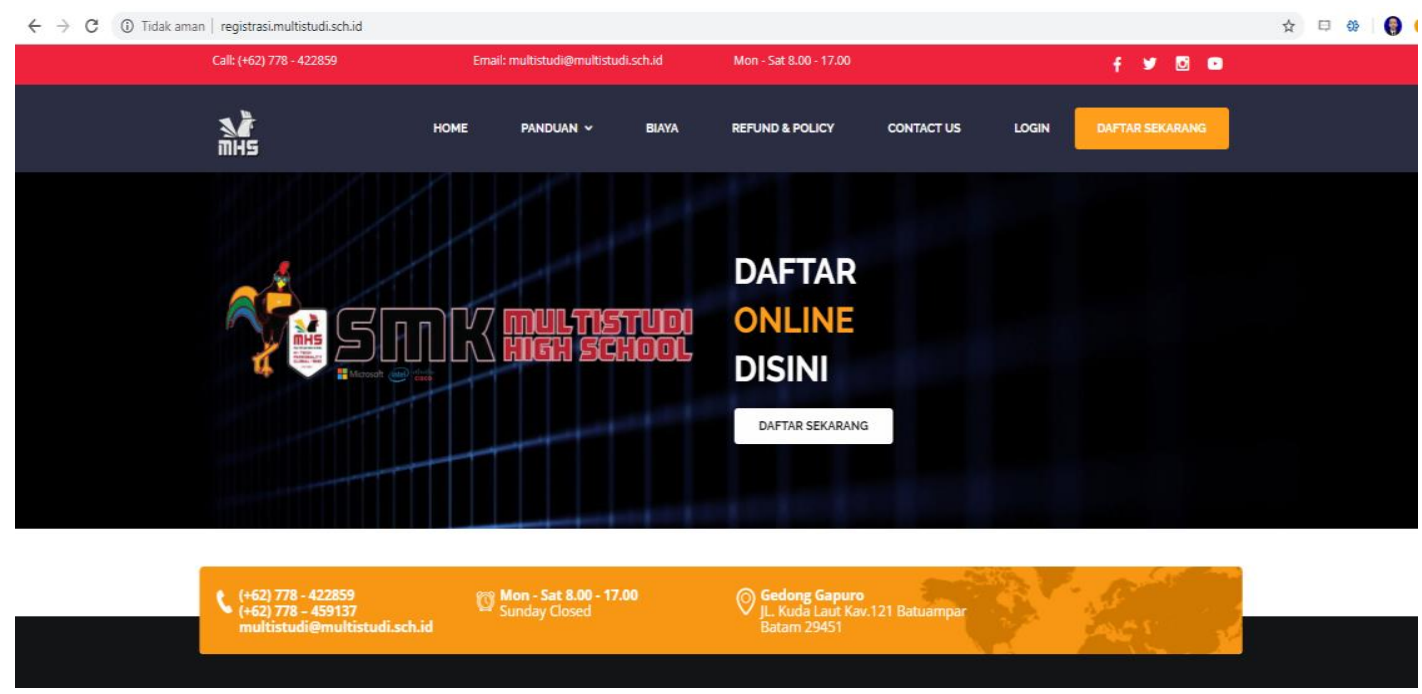

Gambar 3. Menu Registrasi Siswa Baru

Modul tahapan jurusan selanjutnya akan terintegrasi pada tahapan registrasi siswa baru dimana nantinya calon siswa baru menentukan jurusan yang akan dipilih pada system online management registration pada SMK MHS. Menu pada modul ini juga terintegrasi dengan menu pembayaran untuk modul keuangan sekolah. Online management system dalam modul keuangan dapat mengontrol system keuangan secara terpusat melalui beberapa tipe pembayaran yang sudah dikelompokan oleh management sekolah. Sehingga para calon siswa dan siswa di SMK MHS dapat mengetahui informasi yang berkaitan dengan keuangan yang akan dibayarkan pada setiap bulannya melalui portal online management system yang dapat diakses juga melalui link https://sis.multistudi.sch.id/. 


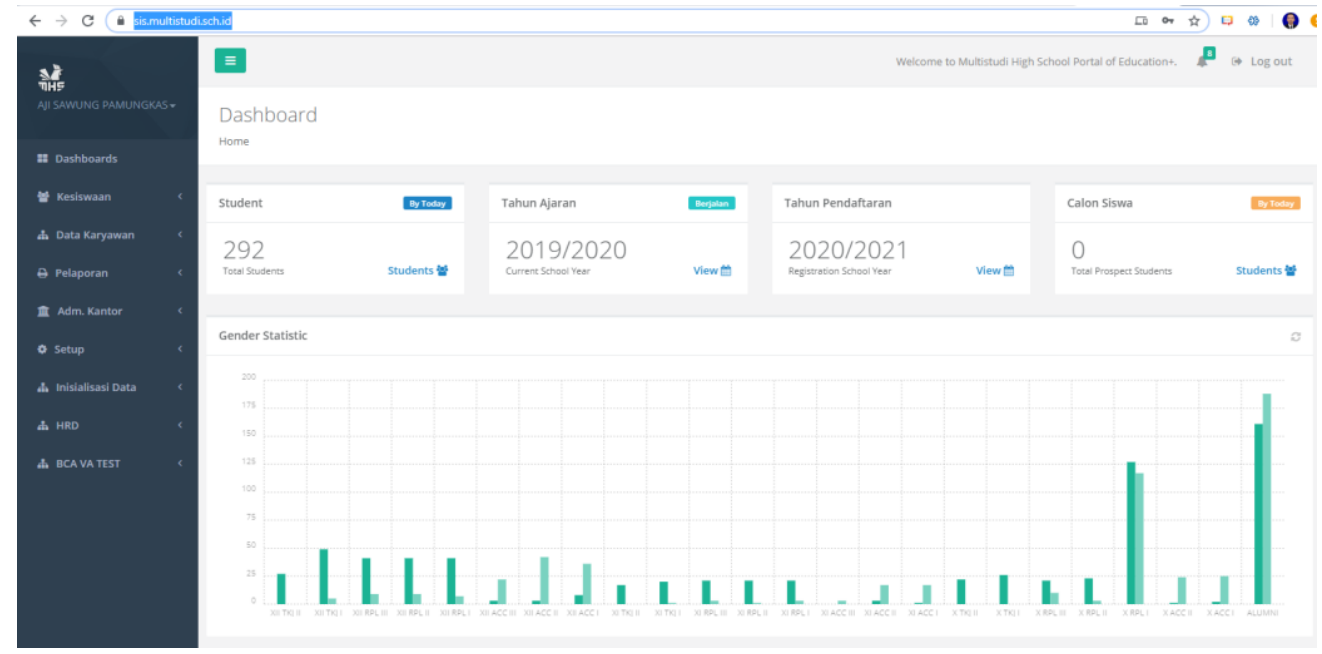

Gambar 4. Tampilan Dashboard Online Management System SMK MHS

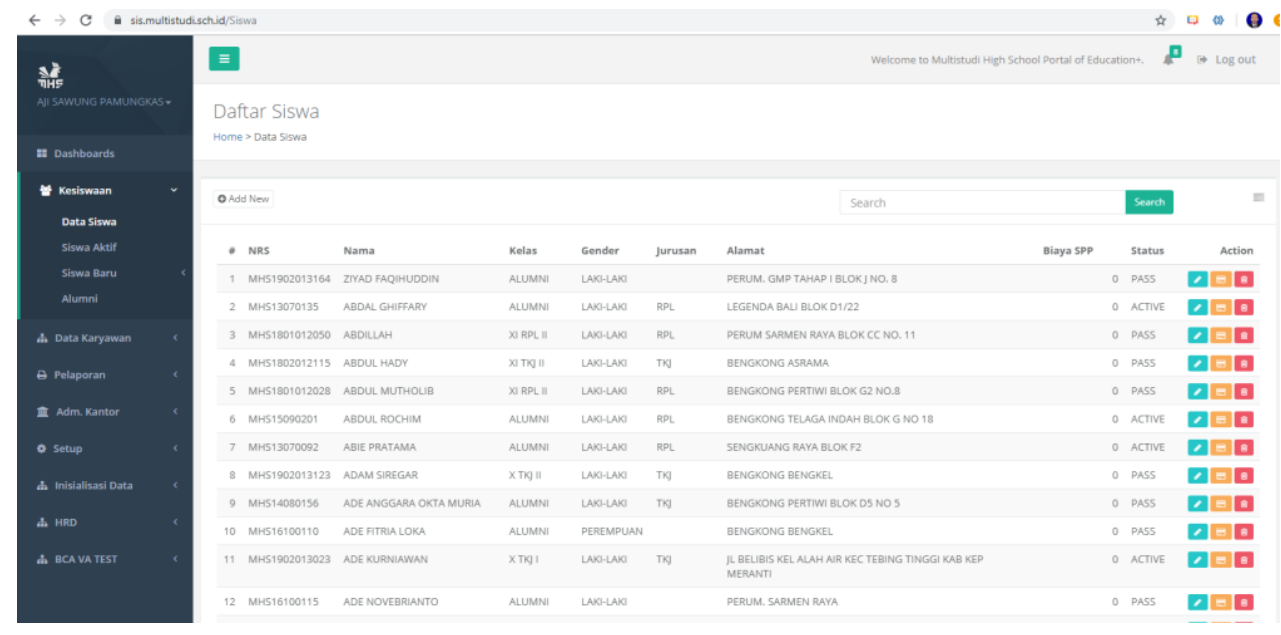

Gambar 5. Menu Data Siswa

Dari menu data siswa ini pengelompokan dilakukan terhadap siswa yang sudah diterima menjadi siswa MHS. Untuk rincian biaya setiap gelombangnya yang terdiri 2 kategori pendaftaran sebagai berikut :

Tabel 1. Biaya Gelombang I untuk pendaftaran Online

\begin{tabular}{|l|c|l|}
\hline \multicolumn{1}{|c|}{ Kategori } & Biaya & \multicolumn{1}{c|}{ Keterangan } \\
\hline FORMULIR & Rp. 162.000 & BAYAR PERTAMA \\
\hline GELOMBANG I & Rp. 1.125 .000 & BAYAR PERTAMA \\
\hline PERLENGKAPAN & Rp. 2.205 .000 & S/D BULAN MEI 19 \\
\hline PEMBANGUNAN & Rp. 1.782 .000 & S/D 1 SEPTEMBER 19 \\
\hline SPP JULI & Rp. 550.000 & S/D BULAN MEI 19 \\
\hline KOMITE/OSIS & Rp. 50.000 & S/D BULAN MEI 19 \\
\hline MOS & Rp. 440.000 & S/D BULAN MEI 19 \\
\hline
\end{tabular}


Tabel 2. Biaya Gelombang I untuk pendaftaran Offline

\begin{tabular}{|l|c|l|}
\hline \multicolumn{1}{|c|}{ Kategori } & Biaya & \multicolumn{1}{c|}{ Keterangan } \\
\hline FORMULIR & Rp. 180.000 & BAYAR PERTAMA \\
\hline GELOMBANG I & Rp. 1.250 .000 & BAYAR PERTAMA \\
\hline PERLENGKAPAN & Rp. 2.450 .000 & S/D BULAN MEI 19 \\
\hline PEMBANGUNAN & Rp. 1.980 .000 & S/D 1 SEPTEMBER 19 \\
\hline SPP JULI & Rp. 550.000 & S/D BULAN MEI 19 \\
\hline KOMITE/OSIS & Rp. 50.000 & S/D BULAN MEI 19 \\
\hline MOS & Rp. 440.000 & S/D BULAN MEI 19 \\
\hline
\end{tabular}

Dari hasil observasi data yang didapatkan bahwa gelombang I untuk pendaftaran online didapat pada tahun ajaran 2018/2019 sebagai berikut :

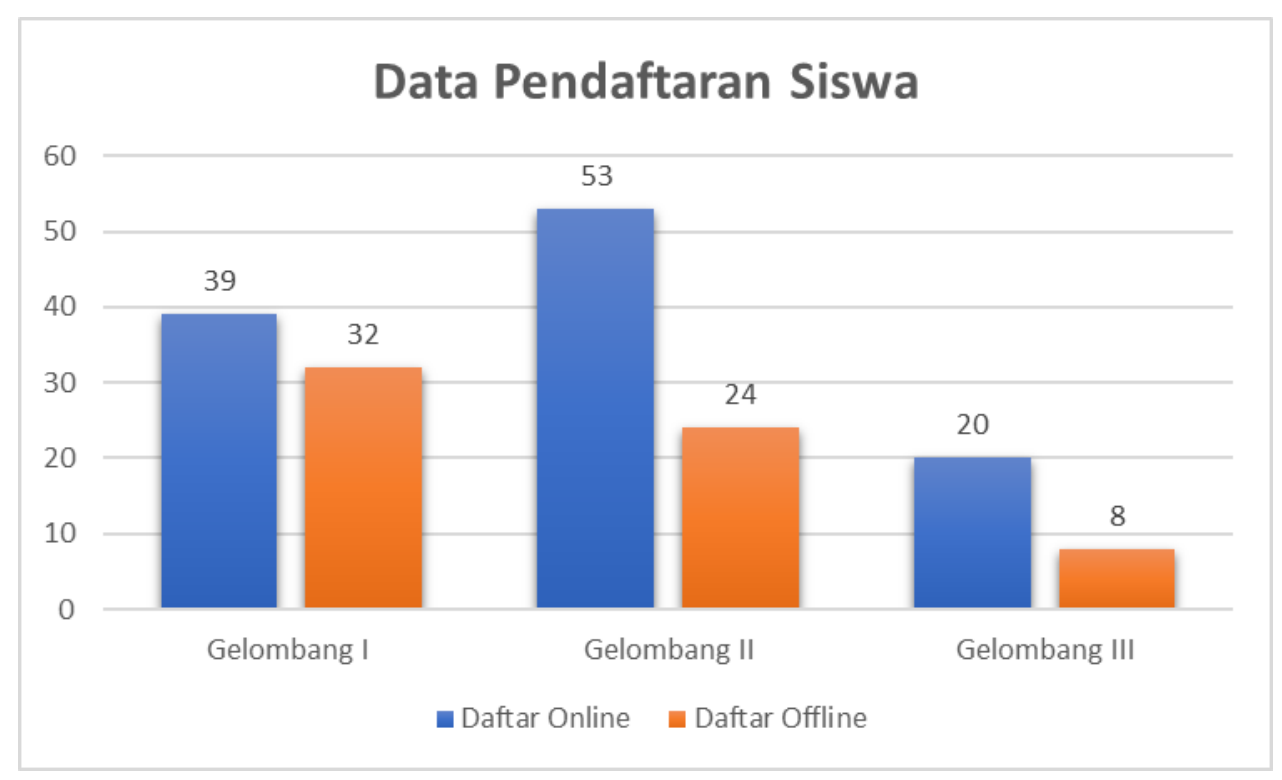

Gambar 6. Grafik Perbandingan Pendaftaran Online \& Offline

Tahapan calon siswa dalam pendaftaran secara online dan offline tergambar lewat flow login standard system berbasis web. Pada langkah prototipe sistem ini , penelitian ini menggunakan server dari GoDady dengan spesifikasi windows server 2016. GoDady adalah provider penyedia VPS yang menyiapkan sistem operasi resources sesuai dengan keinginan kita. Berikut langkahlangkah dalam pembelian server pada Go Daddy:

1. Daftarkan akun dengan menggunakan email yang aktif

2. Setelah registrasi, kita dapat memilih doplet yang akan kita instal dan digunakan untuk dijadikan server cloud kita. Silahkan sesuaikan dengan kebutuhan baik itu kapasistas, location server dan harga yang ditawarkan dari digital ocean.

3. Setelah proses selesai maka semua username dan pasword akan dikirimkan melalui email yang terdaftarkan, langkah selanjutnya adalah setup server yang sudah tersedia. Install database postgresql pada server yang telah selesai di install.

4. Akses server dapat menggunakan Remote Desktop Connection 


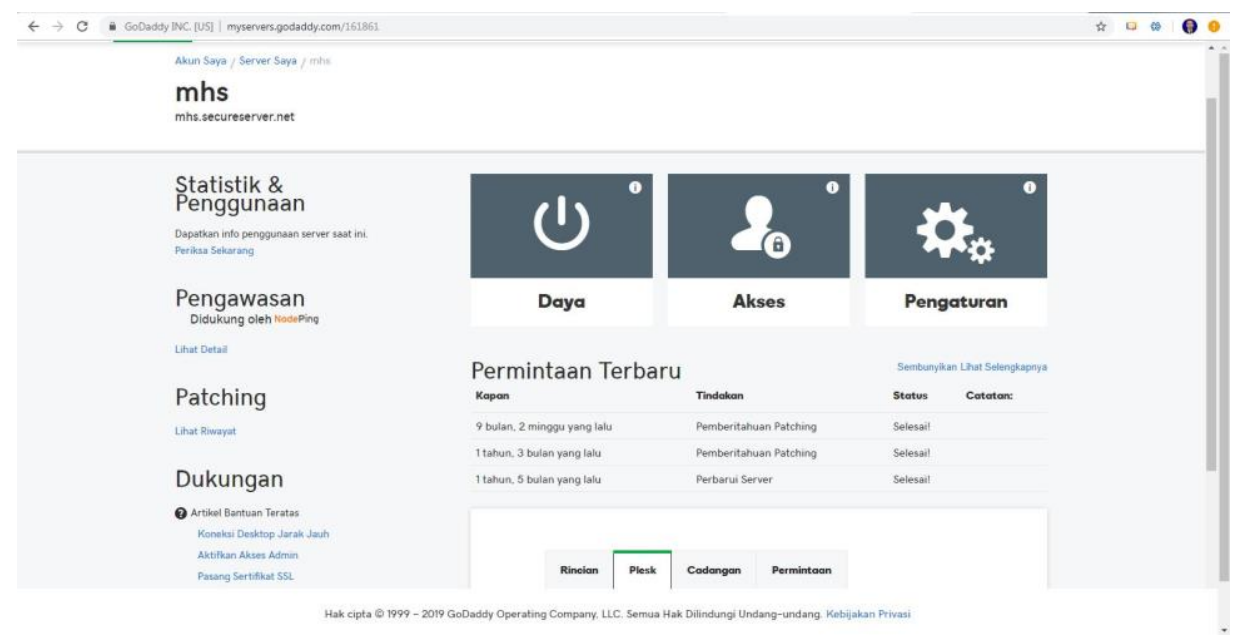

Gambar 7. Dashboard Penyedia Cloud Server

Beberapa hasil yang sudah dilakukan dan uji coba sistem inovasi diantaranya :

1. Online Manajemen semua data sekolah berbasis website

2. Konfirmasi pembayaran calon siswa baru melalu web

3. Integrasi ke email calon siswa baru setelah melakukan pendaftaran

Hasil capaian ini sangat membantu pihak sekolah terkait penerapan online management system pada sekolah tersebut. Dan ini akan memacu ke tahapan berikutnya yaitu mengenai kehadiran siswa berbasis online, sehingga wali murid mengetahui kehadiran peserta didik. Pada tahap pembahasan inovasi registrasi calon siswa baru SMK Multistudi Berbasis online bahasa Pemograman ASP dan database SQL Server yang berbasis langkah rancangan menggunakan metode Black Box. Bug merupakan istilah dari hasil pengujian yang dilakukan dengan cara memasukkan peraturan ke dalam sistem yang di rancang dalam sebuah patform sehingga sistem berfungsi sebagaimana mestinya. Selain melihat fungsi yang sudah berjalan dengan baik dapat juga mengetahui penyimpangan yang terjadi didalam sistem.

\section{Kesimpulan}

Inovasi layanan transaksi digital dapat mempermudah setiap objek yang terlibat dalam mengontrol setiap transaksi pendaftaran secara online, dimana sistem dapat digunakan dengan menggunakan koneksi internet menggunakan teknologi web. Sehingga Pelayanan registrasi online sudah dapat dilakukan dengan cepat sesuai dengan batas kuota yang ditentukan.

\section{Daftar Pustaka}

[1] Amin. S, "Strategi Peningtkatan Kualitas Pelayanan Akademik Pada Sekolah Tinggi," Jakarta, Wahana Akademika, 2017, pp. 194-202.

[2] Asmi, E \& Sahuri, C, "Pelayanan Sekolah untuk meningkatkan kualitas peserta didik," pp. 51-56, 2015.

[3] Dyanthy, L."Aplikasi Sistem informasi Sekolah (SIS) untuk pengelolaan sekolah di kabupaten kudus," Jurnal Sistem Informasi, vol. 5, pp. 323-328, 2015.

[4] Ferraro, S. "Is information and communication technology satisfying educational needs at school? Computers and Education," vol. 122, pp. 194-204, 2018.

[5] Gualdoni, J., Kurtz, A., Myzyri, I., Wheeler, M., \& Rizvi, S, "Secure Online Transaction Algorithm: Securing Online Transaction Using Two-Factor Authentication," Procedia Computer Science, vol. 114, pp. 93-99, 2017. 
[6] Maliq, R. G., Isnanto, R. R., \& Windasari, I. P, "Sistem Pemrosesan Transaksi Pada Toko Bangunan Berbasis Web Dengan PHP dan MySQL," Jurnal Teknologi Dan Sistem Komputer, vol. 2, no. 2, pp. 170-174, 2015.

[7] Membara, E. P., Yulianti, L., \& Kanedi, I, "Sistem Informasi Akademik Smp Negeri 2 Talang Empat Berbasis Web," Media Informatika, vol. 10, no. 1, pp. 72-80, 2015.

[8] Nugroho, I, "transaksi sistem informasi pembayaran spp bimbingan belajar dengan nfc," pp. 11-20, 2015.

[9] Razak, N. A., Jalil, H. A., Krauss, S. E., \& Ahmad, N. A, "Successful implementation of information and communication technology integration in Malaysian public schools: An activity systems analysis approach.," Studies in Educational Evaluation, vol. 58, no. 5, pp. 17-29, 2018.

[10] Saunders, L., Severyn, J., \& Caron, J, "Don't they teach that in high school? Examining the high school to college information literacy gap," Library and Information Science Research, vol. 39, no. 4, pp. 276-283, 2017.

[11] Seesar, Y. A, "Perbandingan Implementasi Insourcing, CoSourcing, dan Outsourcing Dalam Pengembangan Sistem Informasi," Majalah Ilmiah IPB, p. 6, 2014.

[12] Setiyawan, A., Purnama, B. E., \& Sukadi, "Pembuatan Sistem Informasi akademik berbasis web pada sekolah menengah atas negeri 1 ngadirojo Andri Setiyawan," vol. 3, pp. 1-3, 2014.

[13] Shah, M, "Impact of Management Information Systems (MIS) on School Administration: What the Literature Says," Procedia - Social and Behavioral Sciences, vol. 116, p. 2799 2804, 2014.

[14] Tius, R., Margareta, E., Pendidikan, M. M., Kristen, U., Wacana, S., Ismanto, B.,Wacana, S, "Strategi Perencanaan Pembiayaan Sekolah dalam Peningkatan Mutu di SMP Negeri," vol. 2, pp. 195-204, 2017.

@๐०

Digital Zone: Jurnal Teknologi Informasi dan Komunikasi is licensed under a Creative Commons Attribution International (CC BY-SA 4.0) 